Etnográfica

Revista do Centro em Rede de Investigação em

Antropologia

vol. 24 (1) | 2020

Vol. $24(1)$

\title{
Battlegrounds: mobilizing humanitarian discourses in São Paulo detention centers
}

Campos de batalha: mobilizações da gramática humanitária em espaços de reclusão de São Paulo

\section{Fábio Mallart and Ricardo Campello}

\section{(2) OpenEdition}

Journals

Electronic version

URL: https://journals.openedition.org/etnografica/8282

DOI: 10.4000/etnografica.8282

ISSN: 2182-2891

\section{Publisher}

Centro em Rede de Investigação em Antropologia

\section{Printed version}

Date of publication: 1 February 2020

Number of pages: 115-132

ISSN: 0873-6561

\section{Electronic reference}

Fábio Mallart and Ricardo Campello, "Battlegrounds: mobilizing humanitarian discourses in São Paulo detention centers", Etnográfica [Online], vol. 24 (1) | 2020, Online since 25 February 2020, connection on 20 January 2022. URL: http://journals.openedition.org/etnografica/8282 ; DOI: https://doi.org/ 10.4000/etnografica.8282

\section{(c) (i) (8)}

Etnográfica is licensed under a Creative Commons Attribution-NonCommercial 4.0 International License. 


\section{Battlegrounds: mobilizing humanitarian discourses in São Paulo detention centers}

\section{Fábio Mallart and Ricardo Campello}

The text presented here, based on ethnographic research conducted in institutions of social control in São Paulo, such as prisons, juvenile detention units, and custodial and psychiatric treatment hospitals, is an attempt to examine, in spaces of confinement that operate as battlefields, the distinct uses that are intrinsic to the lexicon of human rights. Starting from the power struggles that play out in spaces of detention, we focus on two important vectors: (1) the activation of the discourse of human rights as a tactic of struggle, mobilized by adolescents who dispute for control over internment spaces; and (2) the continuum between the legal lexicon and forms of institutional violence, where the humanitarian discourse is intertwined with the practice of torture in São Paulo detention facilities. In this analysis, it is important to shed light on the distortions, uses and mobilizations that permeate human rights discourses, a prism that allows us to pass from law as a promise of pacification to politics as permanent war.

KEYWORDS: prison, human rights, politics, institutional violence.

Campos de batalha: mobilizações da gramática humanitária em espaços de reclusão de São Paulo - O texto que ora apresentamos, tendo como base pesquisas etnográficas realizadas em instituições de controle social de São Paulo, tais como prisões, unidades de internação para adolescentes e hospitais de custódia e tratamento psiquiátrico, consiste em uma tentativa de perscrutar, em espaços de confinamento que operam como campos de batalha, os distintos agenciamentos intrínsecos à gramática dos direitos humanos. Tomando como ponto de partida os jogos de poder travados em espaços de reclusão, importa prospectar dois vetores: (1) o acionamento da gramática dos direitos humanos como tática de luta, mobilizada por adolescentes que disputam o controle de espaços de internação, e (2) o continuum entre o léxico jurídico e as formas de violência institucional, em que o discurso humanitário se articula às práticas de tortura em unidades prisionais paulistas. No horizonte analítico, importa lançar luz sobre torções, agenciamentos e mobilizações que atravessam os discursos dos direitos humanos, prisma que possibilita a passagem do direito como promessa de pacificação à política como guerra permanente.

PALAVRAS-CHAVE: prisão, direitos humanos, política, violência institucional.

MALLART, Fábio (mallart82@yahoo.com.br) - State University of Rio de Janeiro (UERJ), Brazil.

CAMPELLO, Ricardo (campello.ricardo@gmail.com) - University of São Paulo (USP), Brazil. 


\section{INTRODUCTION}

Incarcerated youths, in order to file accusations against guards to the entities tasked with protecting children's and adolescents' rights, accentuate the marks of torture left on their bodies. Prison authorities, under pressure from the courts, organize mass transfers of "crazy offenders" scattered across ordinary prisons, bring them all together into a makeshift psychiatric ward inside a single prison. In detention centers where there are numerous complaints of prisoner torture - beatings, overcrowding, water scarcity and arbitrary isolation - officials proclaim the Universal Declaration of Human Rights.

Based on ethnographic experiences at institutions dedicated to confining people deemed undesirable and dangerous - such as prisons, juvenile detention centers, and psychiatric wards reserved for inmates with alleged mental disorders - this article seeks to investigate some of the intersections between violence, control, and human rights in the Brazilian penal system.

More precisely, we are interested in examining the ways that the legal-humanitarian repertoire, understood as a heterogeneous set of institutions, practices, regulations, discourses and laws, is mobilized at the "leading edge" - that is, how this repertoire, observed in its concrete expression, is disputed and utilized by actors who operate in spaces characterized by confinement, violence, and torture. To this end, we will analyze specific uses of the discourse of human rights, which transform it into (1) a tactical instrument that permeates relationships of power and confrontation in institutional spaces rife with violent encounters, and (2) a discursive receptacle of institutional violence, where the humanitarian lexicon and the paradigm of rights are intertwined with torture at the hand of state agents.

Looking at the extremities of this normative repertoire, that is, the less juridical aspect of its exercise as it materializes in institutional settings and contexts, allows us to examine certain analytical questions and problems that directly concern us here. How are laws and judicial bodies utilized by operators of the institutions of control and punishment? How is the struggle for rights organized in Brazilian prisons and what are its possible effects? To what extent are discourses defending human rights effective in the political battle over the expansion of freedoms?

This text uses documentary and ethnographic data to reflect on these issues, without any pretense of exhausting them. To this end, certain notions, such as law, politics and violence, will be examined and problematized, in order to carry out an analytical exercise that crosses the void of normative assumptions (Deleuze 1992), shifting our gaze to the confrontation between forces, the struggles and battles that go beyond the legal discourse on paper, accompanying their effects of power in specific institutional spaces.

We should note that this article is part of a set of debates around the political and social uses of the language of human rights, specifically those that 
develop around or within the prison apparatus (Calavita and Jenness 2013; Jefferson and Gaborit 2015; Piacentini and Katz 2016; Marques 2018). Over the past decade, a number of researchers from different countries have focused on the use of humanitarian discourse in prison contexts, its heterodox aims, and its unintended effects.

In this regard, Piacentini and Katz (2016), in their research on the Russian penal system, underline the current maintenance and perpetuation of punitive measures in that country (whose roots go back to the gulags), now permeated by Russia's normative alignment with the European protocols for the guarantee of prisoner rights. Similarly, looking at Canadian prisons, Hannah-Moffat (2001) argues that the legal framework for defending human rights often masks or even strengthens the punitive power of prison institutions.

In Brazil, namely in the state of São Paulo, Adalton Marques (2018) showed how the expansion of public security was founded on democratic and humanist reasoning. Whether under governor Franco Montoro (1983-1987), with his proposals for prison reform and humanization, or following the Carandiru massacre of 1992, where at least 111 prisoners were executed by police forces inside the House of Detention of São Paulo - a period in which a human rights group recommended that São Paulo and federal governments expand their penitentiary systems -, what the author shows us is that the expansion of prisons in São Paulo was mediated by a set of humanist measures and efforts.

Finally, we should note that one of the epistemological movements in this article is to reconsider war as an analytical key to power relations (Proudhon 2011 [1861]; Foucault 1999, 2013; Graham 2011). In this sense, we look at ethnographic material to draw some conclusions about the empirical and analytical relations between violence and law, politics and war. In brief, it is important to consider, looking at punitive practices, the different ways in which the exercise of state and intra-institutional violence are connected, but are also in permanent tension with the legal-normative framework and with discourses associated to the defense of rights.

\section{LAW AS TACTIC}

\section{Fundação Centro de Atendimento Socioeducativo ao Adolescente (CASA)}

"Disputes with the staff are intense. In order to once again make the internment unit a dominated prison, that is, controlled by adolescents, about 150 inmates mobilize themselves. Institutional agents, in turn, react. During various confrontations over control of the institutional space, staff and adolescents put different strategies into play. While the former lessen the intensity of their beatings and practice torture techniques that leave no marks on the bodies of inmates, such as hitting the soles of their feet 
- especially when there are rumors of judicial inspections about to take place at the facility -, adolescents, in order to press for the removal of offending employees, intensify the injuries to their own bodies, making them the living proof of institutional violence. After all, when the members of the Department of Child and Youth Prosecutions (DEIJ) - a judicial body that, among other activities, oversees the detention units - or other entities that defend the rights of children and adolescents go to the unit, generally called in by relatives of the youths, this fact can lead to the removal of oppressive agents, an occurrence that, from the perspective of the inmates, manifests as a central piece on the board where control of the prison plays out. In this ongoing battle, organizations, regulations, discourses, and laws are triggered by different actors who convert legal instruments into war tactics" [authors' notes regarding Internment Unit 37, Fundação CASA, São Paulo, January 2009].

In the lines above, we present some of the confrontational dynamics that characterize the daily life of some of the internment units of the Fundação CASA, an institution responsible for carrying out so-called socio-educational measures for youths aged between 12 and 18 who committed crimes in São Paulo. ${ }^{1}$

At the same time that institutional agents make use of disproportionate physical force, the young inmates, in order to make obvious these recurring aggressions, strategically accentuate the marks of torture on their bodies. In this dispute for control of the unit, entities that defend prisoner rights are called in; court actors are mobilized; the Statute of the Child and Adolescent is constantly evoked. The socio-educational facility becomes a battlefield, and the repertoire of rights is included as a tactical element in this struggle. The legal apparatus is inserted into the confrontation between imprisoned adolescents and security agents, where what is at stake is control of the institutional space - the management of time and activities, the distribution of food, the implementation of leadership positions among the inmates; in other words, control over the functioning of the prison. ${ }^{2}$

1 The Statute of the Child and Adolescent (ECA), a set of laws covering the rights of children and adolescents, was established in 1990 (see "Estatuto da Criança e do Adolescente," Lei federal n. ${ }^{\circ} 8069$, de 13 de julho de 1990). According to its art. 112, once an offense is committed, the competent authority may apply the following sanctions: I - warning; II - obligation to compensate for damages; III - provision of services to the community; IV - probation; V - inclusion in a semi-liberty regime; VI - internment in an educational establishment; VII - any measure provided for in art. 101, I to VI.

2 The use of the term "prison" to refer to internment spaces for adolescents, used both by inmates and by institutional agents themselves, highlights the penitentiary logic that prevails in these institutional spaces and, moreover, the symmetry that exists between the socio-educational juvenile detention system and the adult prison system. For an analysis in this sense, see Mallart (2014). 
First of all, we need to consider the role that detention facilities have played in the process of producing violent conflicts in Brazil. The frequent episodes of widespread violence in prisons - but also beyond them, extending to peripheral neighborhoods of large cities - demonstrate the centrality of the penal and penitentiary apparatus in the diffusion and intensification of so-called urban violence. Cities become the stage for conflicts (Graham 2011; Telles 2015a) and the institutions supposedly tasked with containing conflicts eventually end up producing or intensifying them. From inside the walls and beyond, prisons - either through the production and expansion of criminal groups that later flow into urban spaces, or through their interrelations with other technologies of power, for example when police kill people based on the criminal record of those targets (Mallart and Godoi 2017) - serve as a focus of production and reproduction of violent urban dynamics, whose lethality rates match those of outright wars. ${ }^{3}$

Incidentally, there are more than a few links between prisons and the war rhetoric. Increasingly, the penal apparatus is structured around war. Whether it is in the so-called "war on drug" or the "war on crime," evoked by actors in the judiciary, executive and legislative branches to justify the criminalization, extermination, and systematic imprisonment of black, poor and peripheral populations, or the "war between gangs," produced in great part by this same process of hyper-incarceration that overcrowds the Brazilian prison system, the dull roar of battle can no longer be silenced.

In this context, as in the ethnographic scene that opened this section, the legal apparatus is inserted and mobilized within the social and political conflicts more as a tactical instrument of confrontation than as a mechanism of pacification. The legal and institutional complex that shapes the justice system is instrumentalized as a way to respond to the different interests and positions being disputed, multiplying the clashes they are entrusted to resolve. The legal mechanism is used as a weapon of attack and defense, permeated by the power relations inside and outside the institutions of control. As indicated by Foucault, it is a question of "using tactics more than laws, or, at least, making the use of laws as a tactic" (2010: 293).

To think that strict legal compliance ensures equity in social and political relations is to ignore the instrumental character of law, subjected to the multiple asymmetries that same law produces, legitimizes and deepens. As a result, it escapes the paradigm of rights, whose horizon of justice remains encapsulated by normative assumptions, as if the law itself were not an object

3 In 2016, according to the Monitoring Trends in Violent Deaths report, produced by the Swiss organization Small Arms Survey, more people were killed in Brazil in absolute numbers than in the Syrian and Iraq wars combined. The entity noted 70,200 violent deaths in Brazil that year, which represents $12.5 \%$ of the total number of violent deaths in the world (Mc Evoy and Hideg 2017). 
of struggle whose moving boundaries are in constant dispute (Calavita and Jenness 2013; Telles 2015b). ${ }^{4}$

\section{EFFECTS OF A LEGAL BATTLE}

\section{Franco da Rocha Penitentiary III, metropolitan region}

"The searches at the entrance to the male penitentiary are rigorous. After a series of security procedures, in which fingerprints are collected and photographs taken, the last lock is opened. As the steel gate of Pavilion I slides over the rusty rails, some images emerge: psychiatric patients, in involuntary commitment, are confined in a common penitentiary, wandering aimlessly about the four corners of the small courtyard. One man's right hand trembles nonstop. The movement in his legs accompanies the movement of his hands, effects triggered by the excess of psychotropic drugs. On the other side of the courtyard, where the cells are located, a man of about 60 looks through the bars, onto a horizon that ends at the walls. Another young man, with a series of scars on his head, is circling incessantly around the same spot. The functioning of Pavilion I, according to some of its 109 patients, is identical to that of a common prison: water rationing, overcrowding, absence of work and study activities, physical and verbal abuse. Inside the pavilion, several images are superimposed: men who should be receiving medical treatment, but are incarcerated in a common prison; people with alleged mental disorders subjected to confinement; caged and medicated patients in a prison where there are not even any psychiatrists" [authors' notes regarding Franco da Rocha Penitentiary III, São Paulo, September 2015].

From the ethnographic fragment provided above, we should quickly revisit the conditions that allowed the emergence of the "asylum prison," in which dozens of men are confined in compliance with involuntary commitment orders. ${ }^{5}$ More specifically, we need to return to April 2014, when the two

4 We should stress that the reflections on the normative code as a field in dispute, as well as the later discussions about war and peace, were the object of reflections from different analytical angles by a group of researchers who were part of the FAPESP Thematic Project entitled "Conflict Management in the Production of the Contemporary City: The São Paulo Experience," coordinated by Prof. Dr. Vera Telles (USP Department of Sociology). These are therefore collectively constructed reflections.

5 In general terms, involuntary commitment is applied to persons considered not to be criminally liable - that is, people who at the time they committed an act covered by criminal statutes were not in a position to understand the illegal nature of the act performed. It is noteworthy that this sanction, in cases where hospitalization is considered necessary, must be carried out at Custody and Psychiatric Treatment Hospitals (HCTP) or other appropriate establishments. When there is no need for hospitalization, outpatient treatment should be provided. In practice - and the Franco da Rocha Penitentiary III is a paradigmatic case - psychiatric wards are established in common prisons. 
pavilions of Franco da Rocha Penitentiary III were inaugurated following an accord between the courts and the Secretariat of Penitentiary Administration (SAP). Prior to this period - and this is the point to keep in mind - about 500 people sentenced to involuntary commitment were housed in several prisons in the state while they waited, in some cases for up to three or four years, for an opening at one of the three Custody and Psychiatric Treatment Hospitals in São Paulo, which, it is worth mentioning, are part of the São Paulo penitentiary system.

Given this serious violation of human rights, in which people diagnosed with mental disorders were held in common prisons due to the inability of the government to provide spaces in establishments as required by law, the Public Defender's Office of the State of São Paulo, through its Specialized Center for Prison Situations (NESC), mobilized legal strategies to guarantee the rights of patients who were improperly imprisoned. ${ }^{6}$

Initially, the public defenders petitioned the Secretariat of Penitentiary Administration in order to obtain the names of those being held in ordinary prisons. Once the list was received, the legal clash began. With the identity of "patient-detainees" in hand, the institution mobilized to file hundreds of habeas corpus requests in favor of the incarcerated persons. Following jurisprudence established by the Superior Courts, the aim of this action was to allow these detainees to await vacancies for involuntary commitment in outpatient facilities, that is, outside the prison walls. According to one of the three public defenders who, at the time, composed the Specialized Center for Prison Situations:

"We started to see that in the cases that arrived at the Superior Court of Justice (STJ), all of them, the STJ had ordered that [detainees] wait in outpatient facilities. At first, it was a unanimous decision, peaceful. If you arrived there with two habeas corpus, you could get the person out of prison. And then we said: 'we have to do this for everyone.' So then we met here, another defender came from the Criminal Execution Court (VEC) to help us. We set aside about three weeks and drew up 500 habeas corpus requests for the 500 people who were in prison" [defender 1, interview on April 4, 2016].

The filing of 500 habeas corpus requests at once - a legal tactic put in place to secure rights, insofar as in the absence of openings at proper facilities patients

6 Established in 2006 largely due to mobilization by social movements and civil society organizations, the São Paulo State Public Defender's Office (DPESP) is a government agency that offers the neediest citizens free legal assistance, besides working to promote human rights and to defend individual and collective rights. 
should wait in the halfway facilities -, upon entering the mechanics of the justice system, which escapes the supposed predictability of the normative code, produced effects.

"We started winning several [habeas corpus], but then we learned, from habeas corpus notifications, that patient $[X]$ had been sent to the psychiatric ward of Franco da Rocha Penitentiary III. So we said: 'let's go to Franco [da Rocha] PIII to see what's going on.' Then we went there and we learned that the judge [responsible for assessing the 500 habeas corpus filings] had had this 'fantastic idea' of taking all the people who were in involuntary commitment in the state and putting them in wards [pavilions] that he had emptied out at Penitentiary III; they installed this system in April 2014" [defender 2, interview on April 4, 2016].

If previously the prisoners sentenced to involuntary commitment were spread out across several prisons in São Paulo, after the actions by the Public Defender's Office they were incarcerated in a single prison, constituting a process of concentration. In the struggle for the guarantee of rights, the asylum prison was institutionalized, that is, the existence of a new confinement space for men with alleged mental disorders was formalized - a "provisional prison" for involuntary commitment. According to one of the defenders, after they succeeded in obtaining the release of some of these people, which was a symbolic legal victory - just as the concentration of these subjects allowed, and allows, for the collective action of the courts on even more legal grounds -, they had created "a monster, as part of the effort [of the courts] to defend themselves against an avalanche of habeas corpus [requests], for they were committing an avalanche of illegalities." 7

Faced with the emergence of formally institutionalized psychiatric wards, the legal clash continues. After some inspection visits to Penitentiary III, in conjunction with other groups defending human rights, the Specialized Center for Prison Situations - following a "public civil action" in which reports from other institutions, government decrees, and laws were brought together - requested: (1) partial interdiction, seeking to prevent new persons from being confined in the prison; (2) redirection of patient-detainees, through reassessments within a 30-day period produced by a team linked to the Health Department instead

7 It is noteworthy that, in addition to the Franco da Rocha Penitentiary III, other institutional spaces also emerged after these actions by the Public Defender's Office. This is the case for one of the eight pavilions at the Franco da Rocha Women's Provisional Detention Center, intended for women only, known as "the crazy ward," as well as one of the four pavilions at the Pinheiros Provisional Detention Center III. For the purposes of this article, we focus on the case of Franco da Rocha Penitentiary III, not only because it holds the majority of confined patients, but above all because filings by the Public Defender's Office have focused on this specific institutional space. 
of the Secretariat of Penitentiary Administration; and (3) request for collective moral damages conviction. ${ }^{8}$ These petitions are reviewed in conciliation hearings, where they are still being disputed.

Indeed, one could accompany the conflicting intricacies of these legal clashes that, in this case, seem to bring together laws, decrees, discourses, institutions and actors across multiple instances. However, what is important to bear in mind is the fact that these countless actions and strategies to defend rights, that is, the entire legal-guarantee repertoire activated by the São Paulo Public Defender's Office, once immersed in the workings of the criminal justice system, they led to more abuses and institutional violence. In the struggle for ensuring rights, another confinement space is institutionalized, whose daily operation maintains, and sometimes accentuates, the production of pain, suffering, and torture. The emergence of the "asylum prison" as a way of adapting to the Public Defender's Office's requests demonstrates that in the workings of the justice system, the law is mobilized, twisted and negotiated amid uninterrupted conflicts, giving rise to arbitrary decisions by those who operate the system. In this situation, where the supposed opposition fades, law and violence, legal normative institutions and torture emerge as complementary faces of a continuum.

However, it should be noted that the same strategic action that results in the "asylum-prison," prolonging and accentuating institutional arbitrariness, as we have seen, also results in the release of some patients who were detained and spread out across ordinary prisons. Similarly, it is the concentration of these people in a single space that enabled the Public Defender to act collectively, and no longer individually. These developments demonstrate the ambiguity intrinsic to the political uses of the legal repertoire in spaces of detention, which makes the struggle for the guarantee of prisoners' rights itself an open dispute, endowed with its own limits and possibilities.

Calavita and Jenness (2013), in a study conducted in California prisons on the internal mechanisms provided by the prison administration for filing complaints against institutional abuse, note the arbitrary, partial and coercive uses by prison officials of the investigations and procedures that constitute the system to guarantee prisoners' protection in California penitentiaries. Among other elements, the investigators highlight detainees' reports of physical or disciplinary retaliation following complaints against employees.

8 Governed by Law 7347/85, public civil actions seek to protect the interests of the community. In general terms, this is a procedural instrument provided for in the Brazilian Federal Constitution, which can be used by legitimate entities, such as the Public Defender's Office and the Public Prosecution Service, to defend diffuse or collective interests, or homogenous individuals. 
Meanwhile, Chantraine and Kaminski (2007), addressing the concrete uses of the law in detention, demonstrate that, if on the one hand it is undisputed that the reinforcement of the legal apparatus in the institutional perimeter and, above all, the strengthening of external organs of control, constitute a tool against the abuses of power at a less sovereign administration, on the other hand this same increase allows the institution to reinforce the legitimacy of its mechanisms, revitalizing the prison. Talking with an activist lawyer who works at the International Observatory of Prisons (OIP), the authors show how these professionals can use the legal apparatus as an activist weapon, which helps combat institutional arbitrariness.

On Brazilian soil, by analyzing the inspection reports of the Rio de Janeiro Public Defender's Office as part of its state prison monitoring program, Rafael Godoi (2019) brings together reports of practices, statements and interactions that exemplify the operation of law and authority within prisons, demonstrating the existence of a field of struggle that is not only legal nor restricted to the interior of prisons. Focusing on the clashes between those who wield the law (inspection teams) and those who exercise authority (prison administrators), the author shows how this enforcement program, despite its ephemeral effects of interrupting serious violations of rights, constitutes an available means of combating torture.

In the context of the questions we are interested in debating, what is important to bear in mind is the need to work with the normative lexicon of rights, not in their abstraction, that is, not with the codes that constitute empty manuals (Deleuze 1992), but with their concrete instrumentalization, with subterranean uses immanent to codification, with battles, captures, and unforeseen effects that permeate both legal battles and physical or violent struggles. In the analytical-political horizon, the focus is on the passage from law as a promise of pacification to politics as permanent war, having in the penitentiary and penal system a central factor of the (re)production of conflicts.

\section{WAR AS FOUNDATION OF LAW, POLITICS AS PERMANENT WAR}

In 1861, Pierre-Joseph Proudhon published La guerre et la paix, in which he analyzed the relations of complementarity between the notions of war and peace, as well as the historical and philosophical foundations of law, built on and sustained by confrontation and force. ${ }^{9}$ In his book, Proudhon questions the postulates of classical political philosophy by pointing to the historical interpenetration and conceptual interdependence between states of peace and war. Analyzing the armed conflicts that permeated Western Europe from Antiquity 
to the Modern era, interspersed by the preparatory periods in which peace is marked by permanent invocations of war, the philosopher deconstructs the antinomy between war and peace grounded in the Aristotelian tradition and reiterated by contractualist political theory. For Proudhon, far from being exclusionary states, "peace demonstrates and confirms war; war, in turn, is a demand of peace” (2011 [1861]: 24).

As a result of the philosophical and historiographical dislocation that scrambles the notions of war and peace, Proudhon (2011 [1861]) analyzes the weakened links between law and force, since the legal apparatus has been held since classical Antiquity as an instrument of pacification par excellence. Being established upon the victory of one of the parties involved in a particular conflict, law - as Proudhon understands it - is the codified ratification of the relations established between asymmetric forces, and war, embellished by solemn rituals and justified by the supposed correspondence between moral force and physical force, is characterized as the expression of a judgment.

Commenting on Proudhon's work, Frédéric Gros (2009) stresses the need to unveil the "mythical origin" of the rule of law, whose origins refer to the exercise of violence, which in turn establishes the peace of the victors. The Modern state, historically defined by the seizure of power established through conquest, occupation and massacres, takes the legal apparatus as its instrument of legitimation, giving legal protection to the political relations of domination established within the borders that demarcate a state's sovereignty. If there is concreteness in law, if it is not merely an abstract construction - its roots penetrate the soil of battlefields, fixing its arborescent emergence on an initial victory (Gros 2009: 171).

However, according to Gros's diagnosis, the founding battle of law, just like the war framed in the legal formality that defines and circumscribes the right to use weapons, is now reconfigured by "states of violence," no longer carried out by the traditional soldier but by the terrorist cell, the professional soldier, the "criminal gangs," the security officer. The end of the disciplinary clash between antagonistic troops corresponds to the pulverization of conflicts, which position new actors in the perpetual and ubiquitous scene of combat. Solemn and public war gives way to widespread, spectacular, or underground attacks and counterattacks, whose stage is not restricted to fields crisscrossed by trenches. A new diagram of violence sets in.

In Brazil, the so-called "gang war" reveals the interconnections between penal policy and the exacerbation of violence, redistributed along the social and urban fabric and permeated by the struggle for rights. The expansion and consolidation of the First Command of the Capital (Primeiro Comando da Capital - PCC), one of the main groups that manage illegal activities inside and outside Brazilian prisons, largely derives from the explosion of the São 
Paulo's prison population starting in the mid-1990s, with the group emerging thanks to the struggle for minimum conditions of survival in prisons and the guarantee of rights for detained persons. ${ }^{10}$ Indeed, it would not be an exaggeration to claim that the "gang wars" (waged inside and outside prisons by distinct criminal groups) - whose most recent effect were hundreds of dead inmates in the early days of 2017, many of whom were beheaded in prisons in the Northeast and North of the country - is the result of the criminal and public security policies adopted during the last decades, which overcrowded the always-chaotic Brazilian prison system, demonstrating the cyclical links between politics, violence and the struggle for rights. ${ }^{11}$

It is worth remembering that the penal system as an instrument of combat is analyzed by Michel Foucault in the investigations presented in La société punitive, a course he taught in 1973. There, the philosopher discusses the theoretical formulations of punishment based on the assumption that crime is an attack on society, whereby the criminal assumes the position of "social enemy." The idea that the offender declares war on society is one of the juridical-philosophical pillars on which the theoretical edifice of modern criminal law, and the institutional complex linked to it, are structured. From this postulate, the punitive exercise is understood and formulated by penal reformers - from Beccaria to Bentham, passing through Fichte and Paley - as a public action of counterattack (Foucault 2013).

The recent emergence of the so-called "criminal law of the enemy" revisits the theory of the "social enemy-criminal" against whom the law should act as a coercive instrument of neutralization. In the view of criminologists Günther Jakobs and Manuel Meliá, the need to defend and protect the social body

10 For an analysis of the emergence, expansion and consolidation of the PCC within São Paulo prisons, see Biondi (2010). Regarding the activities of this group in peripheral territories of the city, see Hirata (2010) and Feltran (2011). On the presence of the PCC in detention centers for adolescents, especially in institutional spaces known as "dominated jails," places where no members of this group are even present, see Mallart (2014).

Il From another angle, we should point out that Marques (2018) has already dealt with the links between prison humanization efforts and the explosion of the São Paulo prison system. Regarding the so-called 2017 massacres, just to give an idea of the magnitude of such events, on the first day of the year alone, 56 detainees were killed in the Anísio Jobim Penitentiary Complex located in the state of Amazonas. Among the dead, allegedly executed by members of a faction called the Family of the North (FDN), were members of the PCC, birthed and managed in prisons in the state of São Paulo. A few days later, during a riot that began on January 14 in the Alcaçuz penitentiary in the state of Rio Grande do Norte, also as a result of factional conflict - in this instance between members of the PCC and members of the Crime Syndicate - 26 inmates were killed. In light of this, more than a few government officials and public safety experts have blamed these massacres on "gang warfare," particularly the dispute over drug trafficking routes and/or local corners. From the analytical angle that we are interested in pointing out, the nerve center of this bloody struggle is the prison itself, given that it is within its walls (and the case of the PCC in São Paulo is paradigmatic) that these groups are born, to later spill out into the urban fabric. 
obliges lawmakers to exclude certain offenders from the status of "person," since such individuals have allegedly refused to enter a state of citizenship mediated by law. Penal policy thus assumes the task of eliminating the danger posed by crime in the war waged between the criminal and society: "whoever wins the war determines what the norm is, and whoever loses must submit to this determination" (Jakobs and Meliá 2009: 35).

In this sense, by giving politics the characteristic of permanent warfare, Foucault's inversion of Clausewitz's aphorism provides important analytical clues. Foucault makes use of what he called the "Nietzsche hypothesis," demystifying the supposedly tacit consent provided for in contract theory and mobilizing the notion of war as the analytical grid of power relations. The struggles and confrontations between forces operate as the engine of political order, driven by power tactics that are organized into laws, regulations, and institutions, and whose functionality consists in the renewal of power relations. A kind of "silent war" is re-inscribed in the legal apparatus as a form of sanction, rationalization, and systematization of the violence that manifests itself in these conflicts (Foucault 1999).

\section{HUMAN RIGHTS AS DISCURSIVE ENVELOPE OF PRISON VIOLENCE}

\section{Sorocaba Penitentiary II, interior of the state}

"Asking for help. I am the mother of an inmate housed in this unit. I would like someone to do something, because my son is suffering from hunger in there. The food served at the unit is not sufficient, and the staff will not allow in the food that I bring. I heard that for no reason the prisoners go to the solitary confinement cell, which they call 'the well.' They are often beaten. My son is already paying for what he has done to society and doesn't need to be tortured any more by agents who work in this place. I thank you. I cannot write; I asked someone else to do me this favor. I hope to get a response" [letter received by the Prison Pastoral of the State of São Paulo on September 12, 2016]. ${ }^{12}$

12 The Prison Pastoral is an entity linked to the Catholic Church that has long been active in the prison system, not only providing religious assistance to prisoners but also filing complaints, working with family members, and forming networks with other defenders of human rights. In other works (not yet published) carried out jointly with researchers who also enter the prisons thanks to the Pastoral - which in this sense operates to provide prison access, although this does not imply an instrumentalization of the institution just to make the research feasible - we have discussed the critical and heuristic potentialities of sociological research carried out through the engagement of researchers in militant collectives, striving for a reflection on the links that include militancy, research, and politics. For a brief history of the entity, see Pastoral Carcerária (2010). 
One month later, at the same facility:

"We have the profile of a company here. Our agents are prepared to treat the [inmates]. As Article 1 of the Declaration of Human Rights says, 'all human beings are born free and equal in dignity and rights. They are endowed with reason and conscience and should act towards one another in a spirit of brotherhood.' We have a humanistic vision that we follow in the work done here. We offer work, study, and we have our garden where the [inmates] grow the food we prepare and serve to them" [director of Education, authors' field diary, visit to Sorocaba Penitentiary II, October 20, 2016].

Two overlapping images. Two fragments that at first glance seem to refer to unrelated, distant worlds. However, they are pieces on the same board; they are descriptions of the same space. On the one hand, a letter from the mother of an inmate denounces the violent procedures that the 1800 men - piled up in a space designed for 750 people - go through. On the other hand, an educational worker from the same prison, valuing the treatment offered to inmates, at the same time presents us with posters that quote from the Universal Declaration of Human Rights set forth by the United Nations General Assembly.

As in a hazy picture, the statements by the Sorocaba Penitentiary II official, based on basic human rights precepts, are articulated with the various forms of violence and torture carried out by the staff, establishing a kind of empirical continuity between the humanitarian lexicon and institutional arbitrariness. The accusation presented above was not the only complaint received by the Prison Pastoral that month regarding the same institution. Together with that letter, other 12 letters from family members complained about the lack of food and mentioned the aggressions suffered by their children, husbands, brothers and partners who were imprisoned.

This scenario is not restricted to this specific prison unit, but, on the contrary, extends to the entire penitentiary system of São Paulo and, more broadly, of Brazil. Overcrowding, water rationing, lack of study and work activities are some of the aspects that have long characterized prisons and that - together with frequent beatings, poor diet, and lack of inmates' knowledge about the status of their legal cases - constitute a mechanism that day after day overwhelms, chews up, and crushes bodies and minds. Such situations transform mild illnesses into serious conditions, and long waits into deaths which appear in documents of the Penitentiary Administration without a face, name, or history. Just to have a sense of scale, in 2014 the São Paulo prison system tallied 482 deaths, of which 450 were classified by the SAP as "natural deaths," a category that, considering the scenario just described, points to a slow and progressive death-production process, where inmates are killed bit by bit (Mallart 
2019). ${ }^{13}$ It is in this context that, as Godoi (2017) has shown, torture is diffuse and continuous, constituting an intrinsic aspect of detention, and turning prison, in its daily functioning, into an annihilating machine.

Of course, even under different explanations and intensities, such a state of affairs resonates with the prison systems of other countries. In this regard, Foucault's astonishment regarding Attica prison stands out, as "an eliminating machine, a kind of huge stomach, a kidney that consumes, destroys, crushes and then rejects" (Foucault 2010: 134); Bouagga's (2010) reflections on isolation in the "holes" of the Washington prison system; Gomes's (2011) notes on the disciplinary cells of the Lisbon prison, which are located below the building, next to the sewage pipes; Morelle's (2013) considerations on the Yaoundé prison (Cameroon), especially regarding the so-called Kosovo pavilions - overcrowded, without beds for much of the population, with filthy toilets and frequent thefts. If, of course, there are numerous traits that differentiate penitentiary regimes, there are also traces that unite them: pain, suffering, institutional arbitrariness, punishments within these institutions of punishment.

To take up the specific case of Sorocaba Penitentiary II, what attracts our attention is the emphasis put by the agents on their commitment regarding the humanity of the prisoners, concurrent with the maintenance of various forms of institutional violence. An exposition that focuses on the defense of human rights appears as a discursive practice that masks the perpetuation of maltreatment, aggression, arbitrary isolation and distribution of poor quality food. More than a strategy for concealing abuse, the articles of the Declaration of Human Rights are performed as techniques to protect the unit's administrative staff in the face of entities that supervise and defend prisoners' rights. The institution that was the target of repeated denunciations by the inmates wrapped itself in the humanitarian framework as a way of protecting its agents and its administrative body.

\section{FINAL CONSIDERATIONS}

Overcrowded pavilions. Cells with a capacity for slightly more than ten people holding about 70 bodies. Spaces within prisons that do not even appear in institutional documents, in which prisoners are subject to sanctions that accentuate and multiply their punishment. Trucks that transport prisoners to court hearings, or even medical appointments, parked for hours and hours under the sun, a practice called "microwaving" because of the extremely high temperatures. Housing units for juveniles intended to provide socio-educational measures but operating as prisons, where the "socio-education" is subordinated to

13 Data obtained by Prison Pastoral through an official letter to SAP (SAP Official Letter, number 1458/2015). 
retaliation, beatings and torture. Psychiatric wards in common prisons where "patient-detainees" remain confined and medicalized in an "asylum prison," with no activities, no care, no outlook for improvement. By analyzing the dynamics of institutional spaces whose main objective is to punish and manage populations considered undesirable and dangerous, we sought to observe how the legal-humanitarian repertoire is mobilized at its extremities, being subjected to multiple actors operating at varying scales, and who move within institutions converted into battlegrounds.

The proposition of looking at the normative apparatus from its "edges" proves fruitful in that it permits analytical - and also political - shifts. By using canonical definitions that assume the effectiveness of legal guarantees to analyze Brazilian spaces of confinement, we set off on paths that have already been traveled - and somewhat worn out. From this point of view, we see the mismatch between the isonomic principles of the law and the overwhelming reality of the institutions, a reflection that leads us to ponder the "should" of criminal practices. If, on the one hand, this assumption throws us into a kind of "denunciationism" with no consequences, the effects of which are reduced to the production of immobility, on the other hand, it could even constitute the focus of struggle, in particular by human rights organizations that, in defending strict compliance with the codes, nevertheless are still encapsulated by the normative assumption, disregarding the fact that the law is, in its flexible contours, an instrument and object of struggle (Calavita and Jenness 2013; Telles 2015b), whose effects, moreover, may be unpredictable.

Of course, this does not mean we should disregard the strategic relevance that the defense of human rights has had in recent Brazilian history, especially in terms of the struggles against judicial, legislative and executive authorities to restrain authoritarian practices. What we seek to underline are some of the effects and limits of these struggles. Including in the discussion of the actions by the Public Defender's Office in the case of patients who were illegally confined in common prisons, we demonstrated how, in addition to the tactical mobilization of the legal apparatus, the unfolding of the struggles contributed to the constitution of the "prison asylum," but simultaneously made possible the release of some inmates, as well as the collective action of public defenders. These instances seem to point to an intrinsic ambiguity in the struggle for rights in spaces of detention. As members of the Prison Pastoral, we experienced this ambiguity with each visit to the penitentiary system, manifested somewhere between the exercise of intra-institutional confrontation and, at the same time, the feeling that we are part of the gears of the prison machine. In addition to fighting for the end of prisons and discussions aimed at questioning the very reasons for the prison system, there is the urgency that prevails in these spaces of precariousness and torture, materialized in the need for prisoners who require medicine, a colostomy bag, a single phone call to their 
family members. Indeed, they seem to operate on different timelines - hence the constitutive tension between urgency and politics.

On an increasingly hazy horizon, perhaps it becomes necessary to examine other angles of struggle, starting with the fact that institutions and normative codes are brokered and mobilized on the grounds of war rather than under the cloak of peace.

\section{REFERENCES}

BIONDI, Karina, 2010, Junto e Misturado: Uma Etnografia do PCC. São Paulo, Terceiro Nome. BOUAGGA, Yasmine, 2010, "Qui sont les 'pires des pires'? Des usages des classifications en Supermax aux États-Unis”, Déviance et Société, 34 (2): 201-216.

CALAVITA, Kitty, and Valerie JENNESS, 2013, "Inside the pyramid of disputes: naming problems and filing grievances in California prisons", Social Problems, 60 (1): 50-80.

CHANTRAINE, Gilles, and Dan KAMINSKI, 2007, "La politique des droits en prison: police institutionnelle, militantisme juridique, luttes démocratiques", Champ pénal / Penal Field, available at < https://journals.openedition.org/champpenal/2581 > (last access in February 2020$)$.

DELEUZE, Gilles, 1992, Conversações: 1972-1990. Rio de Janeiro, Editora 34.

Feltran, Gabriel de S., 201 1, Fronteiras de Tensão: Política e Violência nas Periferias de São Paulo. São Paulo, Editora UNESP/CEM/CEBRAP.

FOUCAult, Michel, 1999, Em Defesa da Sociedade. São Paulo, Martins Fontes.

FOUCAUlT, Michel, 2010, Ditos e Escritos IV: Estratégia, Poder-Saber. Rio de Janeiro, Forense Universitária.

FOUCAULT, Michel, 2013, La societé punitive. Paris, Gallimard.

GODOI, Rafael, 2017, “Tortura difusa e continuada”, in F. Mallart and R. Godoi (eds.), BR 111: A Rota das Prisões Brasileiras. São Paulo, Editora Veneta, 117-126.

GODOI, Rafael, 2019, “A prisão fora e acima da lei”, Tempo Social, 31 (3): 141-160.

GOMES, Silvia, 2011, Criminalidade, Etnicidade e Desigualdades: O Crime nos Reclusos dos PALOP, Leste Europeu e de Etnia Cigana e as Percepções dos Guardas Prisionais e dos Elementos da Direç̧ão acerca Deles. Braga, Universidade do Minho, report, available at < https:// repositorium.sdum.uminho.pt/bitstream/1 822/17004/1/Relat\%C3\%B3rio\%20Criminalidade\%20Etnicidade\%20e\%20Desigualdades.pdf > (last access in February 2020).

GRAHAM, Stephen, 201 1, Cities under Siege: The New Military Urbanism. London, Verso.

GROS, Frédéric, 2009, Estados de Violência: Ensaio sobre o Fim da Guerra. São Paulo, Idéias \& Letras.

HANNAH-MOFFAT, Kelly, 2001, Punishment in Disguise: Penal Governance and Federal Imprisonment of Women in Canada. Toronto, Toronto University Press.

HIRATA, Daniel, 2010, Sobreviver na Adversidade: Entre o Mercado e a Vida. São Paulo, Universidade de São Paulo, doctoral thesis. 
JAKOBS, Günther, and Manuel Cancio MELIÁ, 2009, Direito Penal do Inimigo: Noções e Críticas. Porto Alegre, Livraria do Advogado Editora.

JEFFERSON, Andrew M., and Liv S. GABORIT, 2015, Human Rights in Prisons: Comparing Institutional Encounters in Kosovo, Sierra Leone and the Philippines. Basingstoke, Palgrave Macmillan.

MALlART, Fábio, 2014, Cadeias Dominadas: A Fundação CASA, Suas Dinâmicas e as Trajetórias de Jovens Internos. São Paulo, Terceiro Nome/FAPESP.

MALlART, Fábio, 2019, Findas Linhas: Circulações e Confinamentos pelos Subterrâneos de São Paulo. São Paulo, Universidade de São Paulo, doctoral thesis.

MALLART, Fábio, and Rafael GODOI, 2017, "Vidas matáveis", in F. Mallart and R. Godoi (eds.), BR 11 1: A Rota das Prisões Brasileiras. São Paulo, Editora Veneta, 21 -34.

MARQUES, Adalton, 2018, "Sobre o exército prisional de descarte: notas para a desativação da governança democrático-humanista da segurança pública”, in Pastoral Carcerária, Tortura em Tempos de Encarceramento em Massa. São Paulo, Pastoral Carcerária - CNBB, 103-120, available at < https:/carceraria.org.br/wp-content/uploads/2018/12/Tortura-e m-tempos-de-encarceramento-em-massa-2018.pdf $>$ (last access in February 2020).

MC EVOY, Claire, and Gergely HIDEG, 2017, Global Violent Deaths 2017: Time to Decide. Geneva, Small Arms Survey, available at < http://www.smallarmssurvey.org/fileadmin/ docs/U-Reports/SAS-Report-GVD2017.pdf > (last access in February 2020).

MORELLE, Marie, 2013, "La prison centrale de Yaoundé: l'espace au coeur d'un dispositif de pouvoir", Annales de géographie, 691: 332-356.

PASTORAL CARCERÁRIA, 2010, Relatório sobre Tortura: Uma Experiência de Monitoramento dos Locais de Detenção para Prevenção da Tortura. São Paulo, Pastoral Carcerária - CNBB, available at < https://carceraria.org.br/wp-content/uploads/2018/01/relatorio-relatorio_tortur a_2010.pdf $>$ (last access in February 2020).

PIACENTINI, Laura, and Elena KATZ, 2016, "Carceral framing of human rights in Russian prisons”, Punishment and Society, 19 (2): 221-239, available at < https://journals.sagepub. com/doi/10.1177/1462474516665609 > (last access in February 2020).

PROUDHON, Pierre-Joseph, 2011 [1861], “A guerra e a paz”, Revista Verve, 19: 23-71.

TELLES, Vera da S., 2015a, "Cidade: produção de espaços, formas de controle e conflitos", Revista de Ciências Sociais, 46 (1): 15-41.

TELLES, Vera da S., 2015b, "As fronteiras da lei como campo de disputas", in A. Peralva and V.S. Telles (eds.), Ilegalismos na Globalização: Migração, Trabalho e Mercados. Rio de Janeiro, UFRJ, $518-540$.

TOLSTÓI, Liev, 2017 [1865-1869], Guerra e Paz. São Paulo, Companhia das Letras. 